JAROSLAW HUEBNER*

\title{
Nowy Jork - rozwiązania smart w transporcie towarowym i rowerowym
}

\author{
New York - Smart Solutions in Freight \\ Transportation and Bicycle Traffic
}

Streszczenie

Obszary miejskie, które korzystają z technologii informacyjnych w celu rozwiązania różnorodnych problemów społecznych 作 jako "miasta inteligentne".

Wielką uciążliwością wszystkich współczesnych aglomeracji jest problem wzmagającego się ruchu ulicznego. Specyfika dynama waniuczesnikami ruchu, aby zmniejszyć zagęszczenie i zlikwidować „puste przebiegi". To jest właśnie pole do działań dla technologii smart (inteligentnych rozwiązań).

\section{Abstract}

Urban areas which use information technologies in order to solve different social, economic, and environmental issues, and at the same time create durable economic development and high quality of life, are referred to as 'smart cities'.

A great nuisance for all contemporary agglomerations is the problem of the growing street traffic. Owing to the specificity of the dynamics of traffic, attempts at taming it can be undertaken, consisting in logistics programming, that is in managing traffic participants so as to reduce their density and liquidate 'empty rides'. And this is the field of action for smart technologies (smart solutions).

\section{Stowa kluczowe: smart city, logistyka, przeworzy, towary, mobilność, ruch, zattoczenie, wydajiność, aplikacie, ICT
Keywords: smart city, logistics, freight, mobility, traffic, congestion, efficiency, applications, ICT}

Co sprawia, że miasto jest inteligentne? Określenie „inteligentne miasta" słyszymy od lat, ale nie zawsze jest jednoznaczne. Czy wystarczy umieszczenie różnorodnych czujników na każdym rogu ulicy, aby miasto można było nazwać inteligentnym?

Istnieją różne definicje miasta inteligentnego. Większość osób zajmujacych sie tym problemem zgadza sie z teza, że pod ta nazwą rozumie się obszary miejskie, które korzystają z technologii informacyjnych w celu rozwiązania różnorodnych problemów. Problemy te można sklasyfikować jako: spoleczne, gospodarcze i srodowiskowe. Wykorzystanie technik "smart "w celu rozwiązania problemów zaliczanych do którejkolwiek z powyzszych kategoril zawsze musi powodowac tworzenie trwałego rozwoju gospodarczego i wysokiej jakości życia. Jeżeli zachodzą takie relacje, wtedy mamy do czynienia ze zjawiskiem inteligentnego miasta (smart city).

Uciążliwością wszystkich współczesnych aglomeracji jest problem wzmagajajcego się ruchu ulicznego. Specyfika dynamiki ruchu, jak najbardziej nadaje się do próby ujarzmienia
What makes a city a smart city? The term 'smart cities' has been used for years now, but it is not
always clear. Is it enough to install all sorts of sensors on each streecon that a city could be dubbed smart?

There are different definitions of a smart city. Most schesis that this th this subject subscribe to the

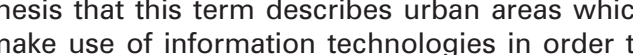
solve all sorts of problems. These problems could be classified as social, economic, and environmensolve problems belonging to any of the categories referred to above always brings about the creation of durable economic development and high quality of life. If such relations occur, we deal with the

phenomenon of a smart city.
A real nuisance for all contemporary agglomeraOwing to the specificity of the dynamics of trafficic attempts at taming it can be undertaken, consising in logistics programming, that is in managing
traffic participants so as to reduce their density and go, polegającego na zaprogramowaniu logistyki, czyli takim czenie i zlikwidować puste przebiegi" środków transportu. Pierwszym nasuwającym się skojarzenie jest tworzenie ograniczeń ruchu (stref parkowania) i systemów parkowania, przede wszystkim dla samochodów osobowych. Jest to obecnie powszechne w wiekszości dużych miast w Polsce i reszcie Europy. To temat stosunkowo dobrze znany i opisany. Bardzo ważnym, ale mniej znanym, zjawiskiem jest zarządzardzo waznym, ale ristya dostaw i przewozów towarowych $w$ dużych aglomeracjach. System taki powstaje w Nowym Yorku i jest pionierski w skali światowej ${ }^{2}$.

Drugim opisywanym systemen bedzie intigentny transport Drugim opisywanym systemem, beqdzie inteligentny transport rónero publiczy jako rozwiazzie transportu miejskiego. Rowniez Nowy Jork jest tu polem badan. W nim system ro-

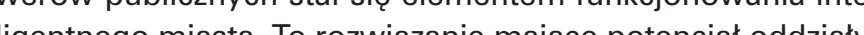
ligentnego miasta. To rozwiązanie mające potencjal oddziały wania na wielu poziomach aktywnosci miasta.

Celowo przedstawiam dwa rożne rozwiązania o całkowicie innym profilu, aby zwrócić uwagę na uniwersalność rozwiązań "smart". Na początku należy wspomnieć o instytucji dbającej o zapewnienie bezpiecznego, efektywnego i czystego ekologicznie) przeplywu osob i towarow ha terenie miasta Nowego Jorku. Jest to Departament Transportu (DOT) ${ }^{3}$. De partament transportu utrzymuje i rozbudowuje infrastrukture transportowa, mającą kluczowe znaczenie dla efektywnos ekonomicznej i jakości życia mieszkańców miasta. Plan strategiczny Departamentu Transportu, noszący jakże wymowna nazwę "Strategic Plan 2016: Safe - Green - Smart - Equitab$\mathrm{le}^{\prime \prime}$, skupia się na poprawie mobilności ruchu i zmniejszeniu zatłoczenia na terenie miasta, między innymi poprzez zachecanie do korzystania z komunikacji zbiorowej i rowerów. DOT projektuje również infrastrukturę rowerową miasta.

W trakcie trzech wyjazdów studialnych do USA w latach 2014 i 2016 stwierdziłem, że doświadczenia wielkich metropolii które zawsze sa krok przed innymi, powinny być poligonem, na którym testuje sie rozwiazania dla reszty świata. Tak dzie je sie na wielu płaszczyznach funkcjonow $w$ technolojich informacyinych, które stuża do rozwiazymawa rizloge munikacynch.

Dla transportu towarowego zawsze najważniejsza jest poprawa wydajności czyli efektywności. Aglomeracja NY jest jednym z centrów globalnej aktywności gospodarczej i aby takim centrum pozostać, musi ciągle poprawiać swoje systemy transportowe. Dotyczy to zarówno wielkich firm transportowych jak też małych przewoźników. W przypadku tych drugich poprawa efektywnosci jest znacznie trudniejsza. Wy maga współdziałania i partnerstwa ze strony władz miasta w zarządzaniu ruchem

NY jest aglomeracją, która w latach 2010-2015 powiększyła liczbę mieszkańców o 370000, a liczba miejsc pracy zwiększyła się o 520000. Od 2000 r. liczba turystów wzrosła o $61 \%$ dochodząc do 59mln osob rocznie. Nie bez znaczenia dla poprawy plynności ruchu jest kwota zasilająca kieszenie nowojorczyków z racji przyjazdów turystów, w roku 2015 wynosita 42,2mId USD. Boom budowlany spowodował budowe liquidate 'empty rides' of means of transport. The first idea that comes into our mind is the creation of traffic limitation (parking zones) and parking common now in most big cities in Poland and in other parts of Europe. It is a relatively well known and described topic.

A very important, although much less known phenomenon is traffic management - logistics of freight supplies and transportation in large aged in New York and it is trailblazing in the global scale.

Another system described herein will be smart public bike transportation as a solution for urban of study. In this city the system of public bikes has become an element of the functioning of a smart city. It is a solution which has a great potential efect on many levels of the city's activities. present here two solutions of completely different profiles on purpose so as to emphasise the should mention an institution which takes care of safe, effective, and clean (ecological) transportation of people and goods within the New York City. It is the Department of Transport (DOT). ${ }^{3}$ The Department of Transport maintains and extend tance for the economic efficiency and the quality of life of city residents. The strategic plan of the Department of Transport, eloquently entitled 'Strategic Plan 2016: Safe - Green - Smart - Equitable focuses on the improvement of the traffic mobiliti limits, by - among other things - encouraging the use of public transport and bicycles. DOT also designs the cycling infrastructure of the city.

During my three study visits to the USA in years of great metropolises, which are always one step ahead of others, should be a training ground, ested. solutions for the rest of the wh the functioning of the city, including information technologies, whose goal is to solve all sorts of urban problems, An element which is always the most crucial for freight transportation is the improvement of it efficiency, that is effectiveness. The New York agglomeration is one of the centres of global activity, and if it is to remain this centre, it has to constantly large transport companies and small carnsirs. the latter case, improvement of transport efficiency is much more difficult. It calls for cooperatio and partnership on the part of the city authorities in the field of traffic management.

New York is an agglomeration which in the years and where the number of jobs grew by 52,000 Since 2002 the number of tourists has increased by $61 \%$, reaching $59 \mathrm{~m}$ people annually. An element which is quite important for the improvement of the traffic liquidity is the amount which reaches ist traffic, which in 2015 equalled USD 42.2bn. The building boom brought about the cons 56,000 new apartments in 2015, and since 2010 office space in Manhattan increased by ca. $1 \mathrm{mil}$ 
transportu towarów i przeznaczenia, a następnie przez określecji w ruchu. Metoda zakłada, że dzięki stosowaniu technik ICT i pojazdów wyposażonych w urządzenia lokalizacyjne bẹdzie można wytyczyć trasy i określić optymalne pory poruszania się po nich pojazdów w celu zminimalizowania zatorów ulicznych. Dodatkową zaletą systemu ma być możliwość śledzenia pojazdów przewożących ładunki niebezpieczne.

Kolejnym ważnym elementem ruch w NY sa rowery, które poprawija wydajność sieci pasażersiej komunikacii Statysty przejazdów suguja realna możliwość zastapien statystyk przejaźów samochodem przez jazde na rowre, pon $88 \%$ przejazdów sument ponieważ mili $22 \%$ do 1 mili a $50 \%$ ponize 3 il. Cayli odleglośi mili, 22\% do 1 mil a $56 \%$ ponizh 3 mil. ozyli odleglosci tatwe do pokona 1 a sila whangh mięsni. Liczba przejazdów rowerowych w NY podwolla sie pomiędzy 2007 i 2011 roku, a potrola sie pomięzy 2007 i 2017 . Sys 2007 i 2011 roku cząl dzialanie w maju 2013 r. Rzędy stojaków z rowerami do uzytku publicznego od kiku lat zwracają uwage na ulicach NY. To whánie jest program Citi Bike kôny jako niskoemisyjna indywidualna forma transportu staje się coraz bardziej przyjazny i atrakcyjny dla ludzi i przedsiębiorstw. Redukcja ilości zanieczyszczeń wiążąca się z mniejszą ilością prywatnych pojazdów pasażerskich, oraz aktywny tryb życia to wkład tego systemu transportu w poprawę zdrowia publicznego. Niebagatelne są tez korzyści ekonomiczne, ponieważ rozwó gospodarczy to między innymi niegenerujący nadmiernych kosztów, wydajny i dostępny transport. Rowery nie są podatne na korki. Zajmują mniej miejsca na drodze i przyczyniaja się do korzystania z transportu publicznego przez zapewnienie „łączności ostatniej mili". Program rowerów publicznych jest sponsorowany przez nowojorski Citibank. Można więc mówić o poprawie w 3 aspektach: gospodarczym, społecznym i środowiskowym. Spowodowało to, zmiane postrzegania marki Citibank. Reputacja firmy i wiażace sie z tym wyniki finansowe bardzo szybko (w ciagu 3 miesiecy) wzrosty. Efekty

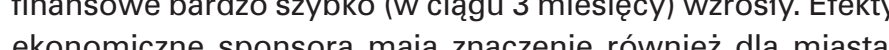
ponieważ rósie zatrudnienie i kwota płaconych podatków. W celuzk rosnie za wać sie na stroni z row i publcz pla wad sle na stán w Nowym Jozu. The New Yor City Departu przejazdow wr Nowy Jork. The New York Ciy Deprostu prze Health szacuje, ze ponad pố miliona nowojorczyków jeździ na co dzien na rowerach. Oczywiscie nie każy samochód moźna zastappic rowerem. Barierami da korzystania z rowerów prywatnych sa: brak bezpiecznych parkingów, kradzieze, wandalizm, hedogodnosci zwizzane z eksploatacja i koszami. Tych wad nie mają rowery publiczne. Ich sukces zależy od dostępnosci stacji rowerowej (stojaka-portu) i prawdopodobieństwa znalezienia wolnego pojazdu. Stwierdzono, że duża ilość rozrzuconych po miescie małych stacji rowerowych zamiast mniejszej ilosci duzych przy tej samej ilosci rowerów może zwiększyć ich wykorzystanie nawet o $30 \%$. Stwierdzono, że jedną z najważniejszych informacji z aplikacji służącej do wypożyczania rowerów jest dokładna informacja na temat dostępności rowerów, czyli optymalizacja wydajności systemu. W tym przypadku rowniez potwierdza się kluczowa traffic jams. An additional advantage of the system is to be the o gerous goods.

Another important element of traffic in New York are bicycles, which improve the effectiveness of the gest a realistic possibility of replacing ca. $88 \%$ of car rides with bike rides, as $10 \%$ of car rides are up to 0.5 mile, $22 \%$ - up to 1 mile, and $56 \%$ below miles. And these are distances possible to be covof bike rides in New York doubled between 2007 and 2011, and tripled between 2007 and 2017. The City Bike system was launched in May 2013. Rows of bike racks with public use bikes have attracted now. They are part of the Citi Bike programme,
which as a low-emission individual form of transport becomes more and more friendly and attractive for people and companies. Pollution reduction connected with a smaller number of private cars, and active lifestyle - this is the contribution of this health. Economic benefits are also quite considerable, because economic development comprises also efficient and easily accessible transport which does not generate excessive costs. Bicycles are no affected by traffic jams. They occupy less space on
the road and they contribute to the use of public transport by providing the 'last mile connection'. The public bikes programme is sponsored by $\mathrm{C}$ tibank, New York. Therefore, one can talk about 3 aspects of improvement here: economic, social, and environmental. This brought about a change in the
way the Citibank brand is perceived. The comp reputation and its financial results connected with it grew over 3 months. The sponsor's economic results are also important for the city itself, as the employment rate and the taxes paid grow. So as to use a public bike, you need to register on a Cir for one's imagination is the dynamism of increase of the number of bike rides in New York. The New York City Department of Health estimates that over half a million New York residents ride bikes on an everyday basis. Obviously, not every car can be replaced with a bicycle. Barriers for using private bikes are the lack of safe parking spaces, thefts, vandalism inconvenience connected with their use, and costs. Public bikes do not have these drawback. Their sucdock - rack) and the probability of finding an available bike. It has been discovered that a large number of small bike stations dispersed around the city instead of a smaller number of large ones, assuming the same total number of bikes, may increase their use even by $30 \%$. It has been discovered that the most important information from the bike rent application is exact information on the availability of bikes, that is optimisation of the system efficiency. In this respect, the key role of logistics in the success of any project is confirmed again, just like i New York City administers nearly 1,0

km) of cycling 2,000 Protected cycling lanes - Cycling lanes located in the street are protected against car traffic by parked vehicles or physical barriers. rola logistyki w sukcesie przedsięwzięcia, podobnie jak to jest w przypadku transportu towarowego.

Miasto Nowy Jork posiada niemal 1000 mil (2000 km) ścieżek rowerowych, sklasyfikowanych w ramach czterech kategorii: Chronione ścieżki rowerowe - ścieżki rowerowe znajdujące się na ulicy są zabezpieczone od ruchu samochodowego poprzez zaparkowane pojazdy lub bariery fizyczne.

Wyznaczone drogi rowerowe sa namalowane linia na drodze, czesto tuż przy liniach wyznaczajacych miejsce prodze, czesto od ruchu drogowego.

Drogi wspólne sa używane przez rowerzystów i motocyDrogi wspolnew uzywane przez rowerzystów i motocysharrow (symbol roweru strzałek) oraz znakam

mi sa nieoznaczone ulice wskazane przez oznakowanie Bike Route lub symbol zielonej drogi. Kierowanie się tymi znakami pomaga rowerzystom poruszać się Wzdłuz wyznaczonej trasy

ie zaleca sie stosowanie oficjalnej mapy rowerowej NYC, aby zaplanować trasę po połączonych ściezkach? . Pełne wykorzystanie rowerow jako „pojazdow ostatniej mill" jest trudne w wypadku zakazu wstępu do wnętrza budynku z rowerem. Nie jest to co prawda problem sieci row rowych, ale rowerow należących do osób prywatnych. Wrozwiazzaniu tego problemu ustalono przepisy Bikes in Buildings (Rowery w budynkach) umożliwiające parkowanie wewnątr. Pracownicy w budynkach komercyjnych wyposażonych w windę towarowa, mają możliwość poproszenia o możliwość parkowania roweru wewnątrz budynku. W tym celu należy: ocenić potrzeby- pracodawca określa liczbe rowerów, które chciałby umieścić. Później trzeba złożyć wniosek o parking dla rowerów do zarządzającego budynkiem. Nastepnie w ciągu 30 dni od otrzymania wniosku właścicie budynku musi stworzyć Bicycle Access Plan (Plan dostepu dla rowerów ) lub zgłosić wyłaczenie ze wzgledu na alternarow rów lub brak wint towarowych w budynku'0. O powadze i rozlegtości dziań ma Jacych na wu promocii rozwój transportu rowerowego maniech świadczy spis: witryn internetowych, instytucji i stowarzyszeń zajmujących się zasobami rowerowymi w NYC

Program Wydziału ds. Transportu Rowerowego NYC nyc.gov/ bikes

Wydział ds. Planowania Miejskiego NYC nyc.gov/planning

Wydział ds. Parków i Rekreacji NYC nyc.gov/parks
Demarcated cycling lanes are marked with a line painted on the road, often right at the lines demarcating parking spaces, and they are marked wit rator painted so as to separate cyclists from the road traffic

Common roads are used by cyclists and motocyclists. They are marked with a sharrow (a symbol signs.

marcated routes are also unmarked streets equipped with the 'Bike Route' sign and a green
road sign. Observing these signs helps cyclists to move along the demarcated route.

is recommended to use an official biker's map of NYC when moving around the city, so as to plan full use of bikes as 'last mile vehicles' is difficult if it is forbidden to enter a building with a bicycle. It is not, however, the problem of bike networks, but bikes owned by private people. So as to solve been developed, allowing to leave bikes inside. Workers in commercial buildings equipped with
freight lifts can ask to be allowed to park their bikes inside the building. In order to do so, it is necessary to estimate the needs - the employer Next, an application for a parking space for bikes must be filed to the building administrator. And then, within 30 days after the receipt of the application, the building owner must draw up a Bicycle Access Plan or report an exclusion due to alterlifts in the building ${ }^{10}$. The seriousness and feightent of actions aiming to promote the development of the bicycle transport in New York can be confirmed with a list of websites, institutions, and asYork City.

of Programme of the Depart
port in NYC nyc.gov/bikes

Department of Municipal Planning in NYC nyc.

gov/partment of Parks and Recreation in NYC nyc. gov/parks

Organisation engaged in cycling education and support
Bike New York bikenewyork.org Bike the Bronx bikethebronx.com
Biking Public Project facebook. Kidical Mass NYC facebook.com/kidicalmassnyc Recycle-A-Bicycle recycleabicycle.org QNS Bike qns.bik il. 4. Scieżka rowerowa na Brooklyn Bridge. Fot. Jarosław Huebner 2014 / Cyclin lane on Brooklyn Bridge. Photo Jarostaw Huebner 2014

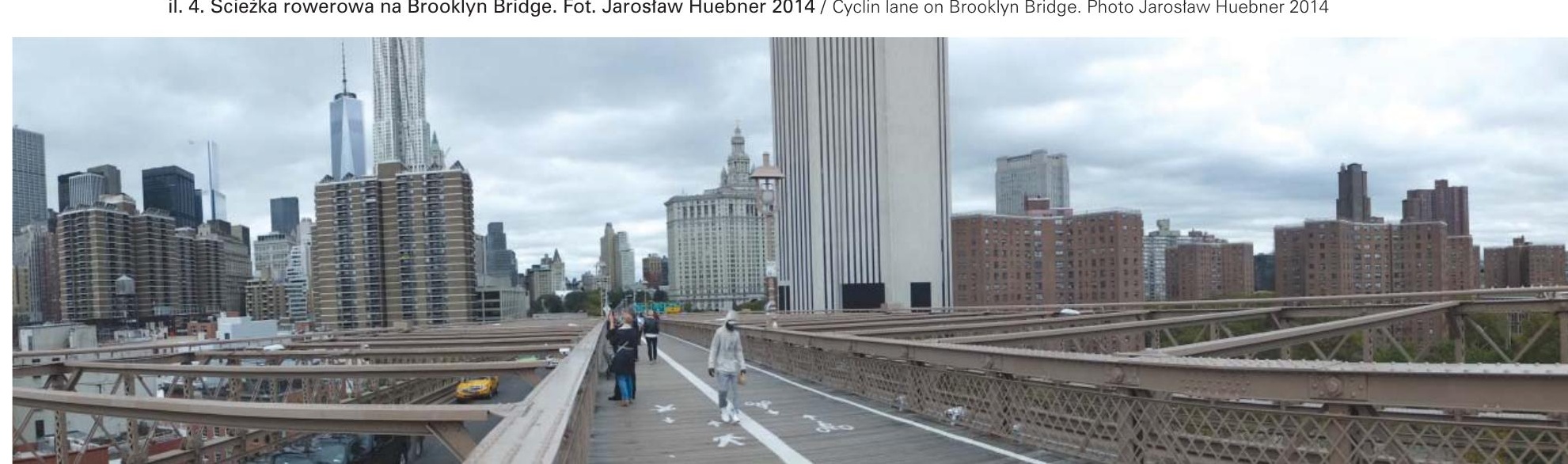


Citi Bike citibikenyc.com

Organizacje zajmujące się edukacją oraz wsparciem

$w$ dziedzinie jazdy na rowerze

Bike New York bikenewyork.org

Biking Public Project facebook.com/BikingPublicProject

Kidical Mass NYC facebook.com/kidicalmassnyc

Recycle-A-Bicycle recycleabicycle.org

QNS Bike qns.bike

Star Track Cycling startrack.nyc

Transportation Alternatives transalt.org

Kluby dla rowerzystów

Century Road Club Association (zawodowy) crca.net

Fast \& Fabulous (LGBT) fastnfab.org

Five Borough Bicycle Club (rekreacyjny) 5bbc.org

Major Taylor Iron Riders (rekreacyjny) majortaylorironriders.

New York Cycle Club (rekreacyjny) nycc.org

OUTCYCLING (LGBT) outcycling.org

Staten Island Bicycling Association (rekreacyjny) sibike.org

WE Bike (dla kobiet) webikenyc.org

Weekday Cyclists in NYC (rekreacyjny) weekdaycyclists.org

Krajowe grupy dla rowerzystó

Bikes Belong bikesbelong.org

Black Girls Do Bike blackgirlsdobike.com

League of American Bicyclists bikeleague.org

National Center for Bicycling and Walking bikewalk.orgs

Tworzenie trwałego rozwoju gospodarczego i wysokiej jakoci życia dzięki sieci zbierającej i przetwarzającej informacje o przewozach towarowych i osobowych to prawdziwie nowojorskie osiągnięcie. Dlatego można stwierdzić, że NY to smart city, przynajmniej w tym aspekcie życia, jaki był tematem artykułu.

\section{PRZYPISY}

Smart-inteligentny (jako cecha oprogramowania i sprzetu)
,New York wrowadzenie nowego systemu transportu towarowego". (3..05.2017. Nick Michell, "Cities Today", ktory jest globalnym magazyn zawie
raiacym analizy, komentarze w zakresie zrównowazonego rozwoju obszarón Na podstawie http://Mww.nyc.gov

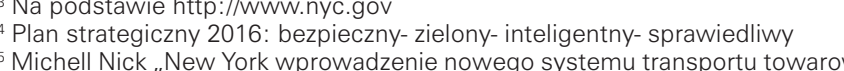
go", Cities Today, 23 maj 2017. Waze - GPS, Mapy \& Korki, jedna z najwieksszych aplikacji nawigacyinych in-
formujacecei o korkach, oparta na spotecznosci.Sprzedawca, Waze navigation, Programista Electra

astatnia mila Pojecice przeniessione $w$ tym opracowaniu do komunikacail. Puls Biznesu, 12-08 sie-tzw-ostatnia-mila-764750 8 "Pod pojeciem technologii informacyinych i komunikacyinych w skrócie ICT,
$z$ ang. information and communication technologies, nazywanych zamiennie

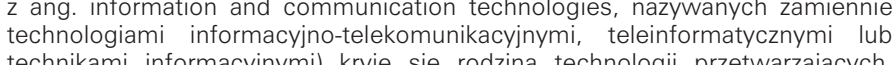
technikami informacyinymi kryje sie rodzina technologii przetwarazajacych,
gromadzacych i przesylajacych informacje $w$ formie elektronicznej. Weíszym

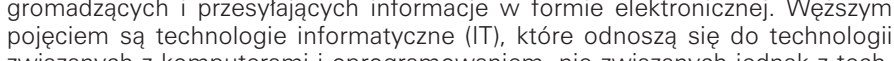

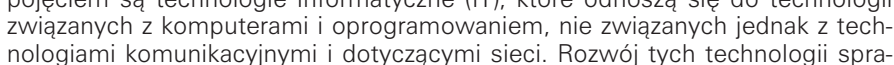
nologiami komunikacyinymmi I dotyczacymi siecl.
wia, że oba pojecia staja sie coraz bardziej spojine, bedacy przy tym mototorem rozwoju crwilizacyinego, spotecznego i gospodarczegoo," Wedtug definiciji Gtów nego Urzedu Statystycznego,
cyino-komunikacyine.htm!

Mapa jest dostepna na stronie nyc. gov/bikema
o informacja za www.nyc. gov/bikesinbuildings
Star Track Cycling startrack.nyc

Transportation Alternatives transalt.o

Century Road Club Association (professional) crca.

Fast \& Fabulous (LGBT) fastnfab.org

Five Borough Bicycle Club (recreational) 5bbc.org Major Taylor Iron Riders (recreational) majortay

每

Now York Cycle Club (recreational) nycc.org

Staten Island Bicycling Association (recreational)

sibike.org

WE Bike (for women) webikenyc.org

Weekday Cyclists in NYC (recreational) weekdaycyclists.org

National cycling groups

Black Girls Do Bike blackgirlsdobike.com

League of American Bicyclists bikeleague.org

bikewalk.

Creation of durable economic development and high quality of life thanks to a network collecting and processing information on freight and passenger transportation is a real achievement New New York is a smart city, at least in the auded of life which constitutes the subject matter of this paper.

ENDNOTES

Smart as a property of software and hardware

23.05.2017, Nick Michell, 'Cities Today', which is asten

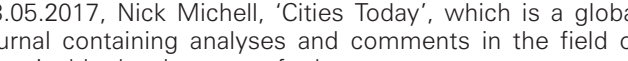
sustainable development of urban areas.
On the basis of http:/ wwwn nyc gov

${ }^{4}$ Strategic Plan 2016: Safe - Green - Smart - Equitable
${ }^{5}$ Michell Nick'New York Introduction of a New Freight Trans port System', Cities Today, 23 May 2017 . -based navigation applications informing on traftic jams. Se The last mile - a term used in logistics and e-commerce. The last mile transport solutions taking care of customer's is transferred to transportation. 'Puls Biznesu', $12-08-2014$ https://Www.pb.pl/zawistowski-W-logistyce-
-kluczowa-staje-sie-tzw-ostatnia-mila-764750

${ }^{8}$ 'The term information and communication technologies, or ICT, also referred to as information and telecommuni-
cation technologies, teleinformation technologies, or information techniques, comprises a family of technologies
processing, collecting, and transferring information in a diWhich refers tortower term is intormation technologies software, but not connected with communication technologies and technologies concerning grids. Development of and a motor of the civilisational, social, and economic $d e-$ velopment. According to the definition of the Polish Centra informacyino-komunikacyine html The map is available on the website nyc.gov/bikema
"o Information after www.nyc.gov/bikesinbuildings

\section{BIBUOGRAPHY}

Chainic T.G., Gendreau M., Potvin J.Y. Intelligent freight
transportation systems: Assessment and the contribution of

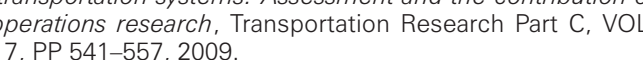
[2] Emmelhainz, M.A. Electronic Data Interchange: A Total
management Guide. Van Nostrand Reinhold, New York, 1990. management Guide. Van Nostrand Reinhold, New York, 1990.
[3] Golob, T.F., Regan, A.C., Trucking industry preferences
for traveler information for drivers using wireless internet.
LITERATURA

11) Crainic T.G., Gendreau M., Potvin J.Y., Intelligent freight-transportation sys-

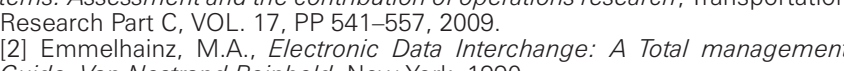
Guide. Van Nostrand Reinhold, New York, 1990 .
12. Ene: A Total management on for drivivers using wireless internetenanabled devices, Transportation Re search Part C: Emerging Technologies, VOL $133(3)$, , PP $235-250,2005$.
$[4]$ Hall lenbeck M.E., McCormack E., Nee J., Wrigh D., Freight Data From Inte(igent Transportation System Devices, 2003
5) loannou P. A., Intelligent Freight Transportation (Automation and Control

Engineering, CRC press 2008.
[6] IIt telligent Freight Transport, PTV Compass International magazine, 2010
[7] Koolhaas R., Deliryczny Nowy Jork, Wydawnictwo Karakter, Kraków [8] Mirzabeiki V., An Overview of the Freight Intelligent Transportation SysCongress, Busan, South Kored 20 [9] praca zbiorowa, Nowy Jork, Wydawnictwo ExpressMap, Warszawa 2015
$[10]$ Srour F.J., Newton D., Freight-Specific Data Derived from Intelligent Iransportation Systems Potential Uses in Planning Freight Improvement Projects, Transportation Research Board, 2006.
[111 W Westerheim H., Smart Freight Transport in Urban Areas, European comMission, 2011 . . W Walton C.M. Freight Data Needs At The Metropolitan Level
And The Suitability Of Intelligent Transportation Systems In Supplying MPOS With The Needed Freight Data, 2004

Strony internetowe (odstony pomiędzy 15.06.2017 a 06.07.2017)

[1] http://WwW.nyc. gov/htm//dot//htm//bicyclists/biketips.shtml
[2] https://www.finchandbeak.com/1108/smart-cities-smart-transit-bike-shares.htms
[3] https://cities-today.con

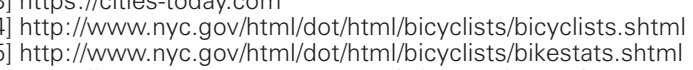

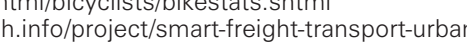

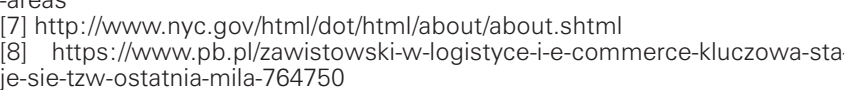

enabled devices, Transportation Research Part C: Emerging (4) Hallonb $K$ M E. Mc Data From Intelligent Transportation System Devices, 2003 6] Intelligent Freight Transport, PTV Compa 8] Mirzabeiki V.. An Overview of the Freight Intelligent Trans portation Systems, Proceedings of the 17 th Intelligent Trans-
portation Systems (ITS) World Congress, Busan, South Korea [9] collective work, New York, ExpressMap Publishers, War10] Srour F.J., Newton D., Freight-Specific Data Derived from Intelligent Transportation Systems Potential Uses in Planning
Freight Improvement Projects. Transportation Research Board. 11] Westerheim H., Smart Freight Transport in Urban Areas. [12] Victoria I.C., Walton C.M. Fre Fright Data Needs At The Me tropolitan Level And The Suitability Of Intelligent Transportation
Systems In Supplying MPOs With The Needed Freight Data. Websites (viewed between 15062017 and 06072017 ):

[1] http://www.nyc.gov/htm//dot/html/bicyclists/biketips.shtml
[2] https://www.finchandbeak.com/1108/smart-cities-smart-transit-bike-shares.htm

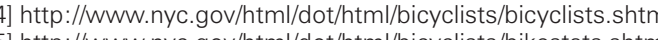

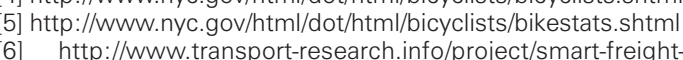
transport-urban-areas $/$ http://www.nyc.gov/htm//dot/html/about/about.shtml 18) https:I/WwW.pb.pl/zawistowski-W-logistyce-1-e-commerce 